\title{
TRIMBLE M3 1" AND SOUTH NTS-362R TOTAL STATION ANGLE MEASUREMENT ACCURACY ANALYSIS
}

\author{
Grzegorz OLENIACZ11, Izabela SKRZYPCZAK, Tomasz ŚWIĘTOŃ \\ Rzeszow University of Technology, Rzeszów, Poland
}

\begin{abstract}
The main purpose of this study was to obtain information about the actual precision of angle measurements with two instruments (Trimble M3 1 "and South NTS-362R), realizable in given measurement conditions. This object is achieved by using a simplified method of testing instruments contained in the PN-ISO 17123-3 standard [1]. This is a continuation of research described in [2], carried out on the same test base, but this time in a different, less favorable field conditions. The use of the same instrument has created an opportunity to compare and analyze the measurement results. The scope of work includes the measurement and results preparation along with statistical processing of the obtained results for both instruments.
\end{abstract}

Keywords: ISO standard, angle measurement, accuracy analysis

\section{STUDY USING SIMPLIFIED METHOD IN ACCORDANCE WITH PN-ISO 17123-3 STANDARD}

According to the PN-ISO 17123-3 standard [1] theodolites testing can be performed using two procedures. Full testing procedure, allows to define the highest achievable accuracy of the instrument in a variety of possible conditions. While a simplified testing procedure gives information what is the accuracy of measuring equipment in the current measurement conditions. Continuing research described in [2] was used simplified procedure.

\footnotetext{
${ }^{1}$ Corresponding author: Rzeszow University of Technology, Faculty of Civil and Environmental Engineering and Architecture, Department of Geodesy and Geotechnics, Al. Powstańców Warszawy 12,35-959 Rzeszów, tel. +48178651012, e-mail: oleniacz@prz.edu.pl
} 
The subject of testing were two total stations: Trimble M3 1 "(Fig. 1a) and South NTS-362R (Fig. 1b).

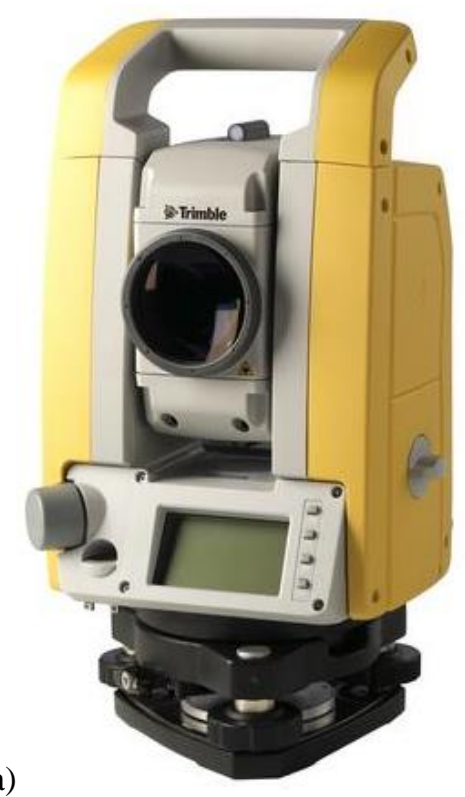

b)

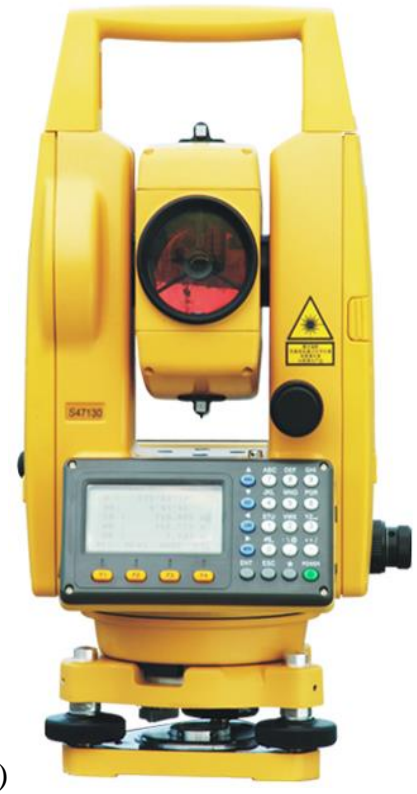

Fig. 1. Total stations used in the test: a) Trimble M3 1" source: trimble.com; b) South NTS-365R, source: southinstrument.com

Comparison of the basic technical parameters relating to horizontal and vertical angles measurement of the tested instruments are listed in Table 1.

Table 1. Basic specification of the instruments

\begin{tabular}{|c|c|c|}
\hline Feature & Trimble M3 1" & South NTS-362R \\
\hline $\begin{array}{c}\text { Accuracy of angle } \\
\text { measurement }\end{array}$ & $1{ }^{\prime} / 5^{\mathrm{cc}}$ & $2{ }^{\circ}$ \\
\hline Diameter of encoder disk & $62 \mathrm{~mm}$ & $79 \mathrm{~mm}$ \\
\hline Measuring method & Absolute & Absolute \\
\hline Telescope magnification & $30 \mathrm{x}$ & $45 \mathrm{~mm}$ \\
\hline Effective aperture & $40 \mathrm{~mm}$ & $1^{\circ} 30^{\prime}$ \\
\hline Field of view & $1^{\circ} 20^{\prime}$ & $1 \mathrm{~m}$ \\
\hline Minimal Focus dictance & $1,5 \mathrm{~m}$ & \pm 3 \\
\hline Auto compensator & Dual axis, Liquid-electric & Dual axis, Liquid-electric \\
\hline $\begin{array}{c}\text { Working range of } \\
\text { compensator }\end{array}$ & $\pm 3,5^{\circ}$ & \\
\hline
\end{tabular}

Measuring base for horizontal angles consisted of four clearly identifiable, clearly visible targets, symmetrically arranged around at the height of the horizon of telescope. The test consisted of three series of measurements to four points. 
Measured points were observed in each series in face I position of the telescope clockwise and in face II position of the telescope in opposite direction to clockwise. Bearing of encoder disk was changed by about 67 gon after each series. Measurement base for vertical angles were four targets located on the wall of the building, covering about 30gon range of vertical angle. Measurements were carried out with both instruments at the same time from the two adjacent stations. In contrast to the measurement conditions during previous research targets were not equally exposed. Two of them were in the shade, and the other two were heavily sunny. They were also different weather conditions: higher air temperature and strong wind.

\section{ANALYSIS OF HORIZONTAL AND VERTICAL ANGLE MEASUREMENT ACCURACY OF TESTED IMSTRUMENTS}

On the basis of field measurements, calculations were carried out according to the recommendations of PN-ISO standard [1]. The results of measurements and calculations are summarized in Tables 2 and 3, for Trimble M3 1 "and in Tables 4 and 5 for South NTS-362R.

Table 2. A simplified method of horizontal angle testing for Trimble M3 1"

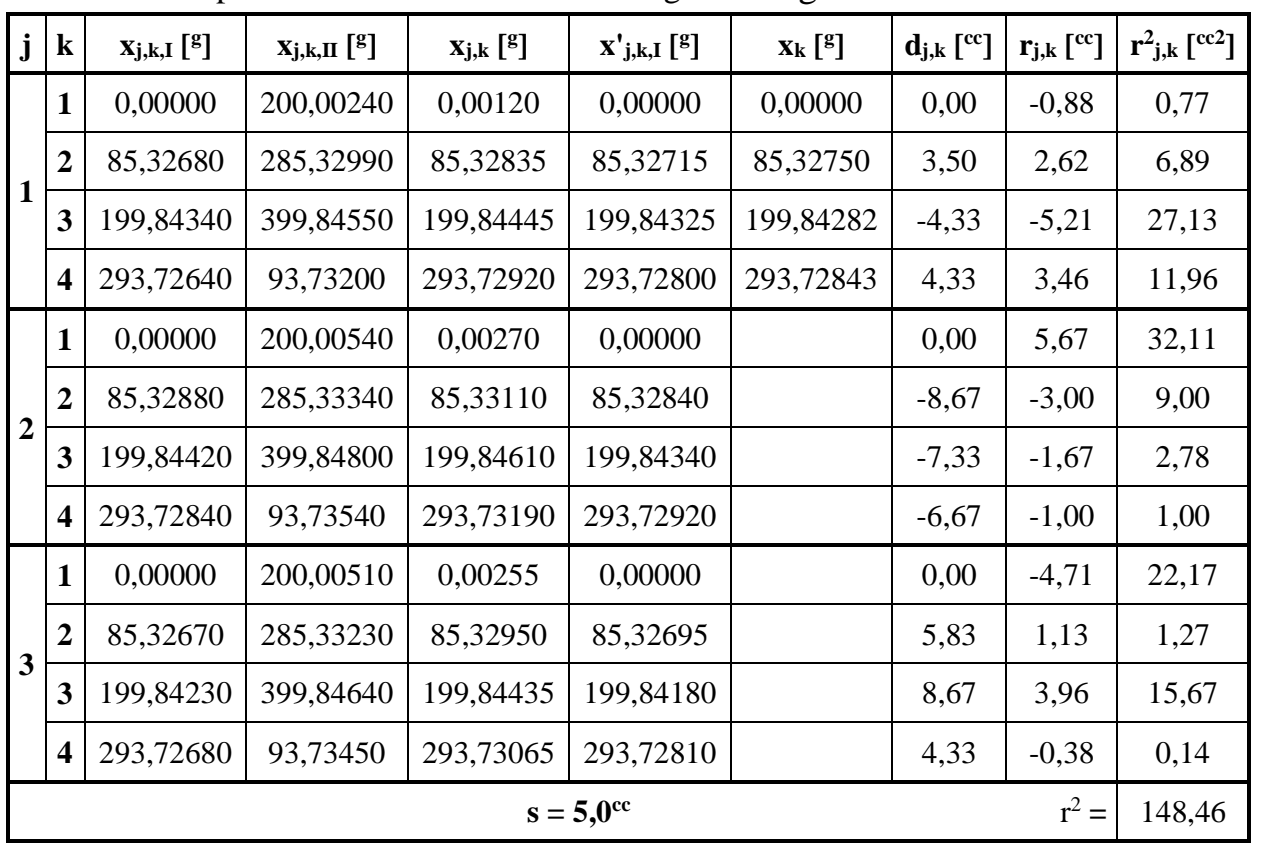


Table 3. A simplified method of vertical angle testing for Trimble M3 1"

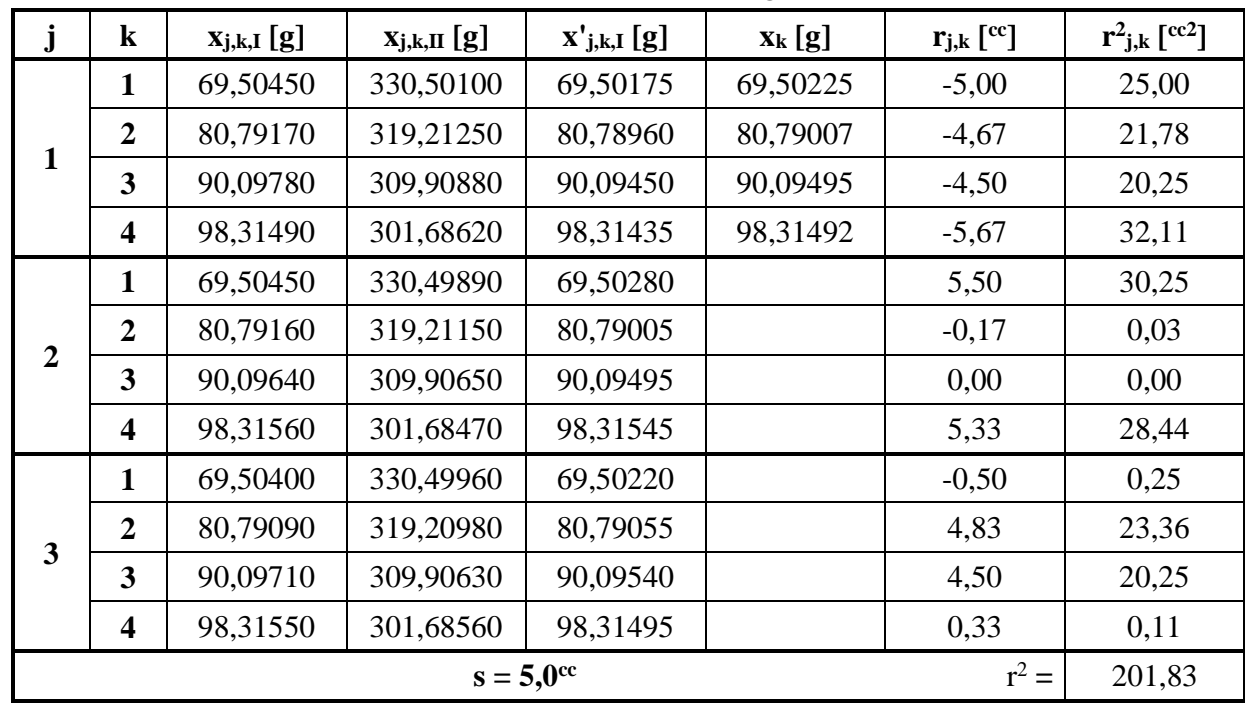

The resulting accuracy of Trimble M3 for horizontal angles is $0,5 \mathrm{mgon}$ (Table 2). The same result is for vertical angles (Table 3). So these are the values that are at the limit of accuracy the specified by the manufacturer and declared in a factory data (Table 1).

Table 4. A simplified method of horizontal angle testing for South NTS-362R

\begin{tabular}{|c|c|c|c|c|c|c|c|c|c|}
\hline $\mathbf{j}$ & $\mathbf{k}$ & $\mathbf{x} \mathbf{j}, \mathbf{k}, \mathbf{I}{ }^{\left[{ }^{\mathrm{g}}\right]}$ & $\left.\mathbf{x}_{\mathbf{j}, \mathbf{k}, \mathbf{I I}}{ }^{\left.{ }^{\mathrm{g}}\right]}\right]$ & $\left.\mathbf{x}_{\mathbf{j}, \mathbf{k}}{ }^{\mathrm{g}}\right]$ & $\left.\mathbf{x}_{\mathbf{j}, \mathbf{k}, \mathbf{I}}{ }^{\left.{ }^{\mathrm{g}}\right]}\right]$ & $\mathbf{x}_{k}{ }^{\left[{ }^{\mathrm{g}}\right]}$ & $\mathbf{d}_{\mathrm{j}, \mathrm{k}}\left[{ }^{\mathrm{cc}}\right]$ & $\mathbf{r}_{\mathbf{j}, \mathbf{k}}\left[{ }^{\mathrm{cc}}\right]$ & $\left.\mathbf{r}_{\mathrm{j}, \mathrm{k}}{ }^{\mathrm{ccc} 2}\right]$ \\
\hline \multirow{4}{*}{1} & 1 & 0,00000 & 200,00160 & 0,00080 & 0,00000 & 0,00000 & 0,00 & $-2,12$ & 4,52 \\
\hline & 2 & 100,73590 & 300,73880 & 100,73735 & 100,73655 & 100,73615 & $-4,00$ & $-6,12$ & 37,52 \\
\hline & 3 & 194,40210 & 394,40300 & 194,40255 & 194,40175 & 194,40235 & 6,00 & 3,87 & 15,02 \\
\hline & 4 & 290,37470 & 90,37490 & 290,37480 & 290,37400 & 290,37465 & 6,50 & 4,37 & 19,14 \\
\hline \multirow{4}{*}{2} & 1 & 0,00000 & 199,99930 & $-0,00035$ & 0,00000 & & 0,00 & 3,50 & 12,25 \\
\hline & 2 & 100,73450 & 300,73670 & 100,73560 & 100,73595 & & 2,00 & 5,50 & 30,25 \\
\hline & 3 & 194,40080 & 394,40370 & 194,40225 & 194,40260 & & $-2,50$ & 1,00 & 1,00 \\
\hline & 4 & 290,37550 & 90,37580 & 290,37565 & 290,37600 & & $-13,50$ & $-10,00$ & 100,00 \\
\hline \multirow{4}{*}{3} & 1 & 0,00000 & 200,00060 & 0,00030 & 0,00000 & & 0,00 & $-1,37$ & 1,89 \\
\hline & 2 & 100,73480 & 300,73770 & 100,73625 & 100,73595 & & 2,00 & 0,63 & 0,39 \\
\hline & 3 & 194,40230 & 394,40370 & 194,40300 & 194,40270 & & $-3,50$ & $-4,88$ & 23,77 \\
\hline & 4 & 290,37370 & 90,37480 & 290,37425 & 290,37395 & & 7,00 & 5,63 & 31,64 \\
\hline & & & & & $\mathrm{s}=6,8^{\mathrm{cc}}$ & & & $r^{2}=$ & 277,38 \\
\hline
\end{tabular}


Table 5. A simplified method of vertical angle testing for South NTS-362R

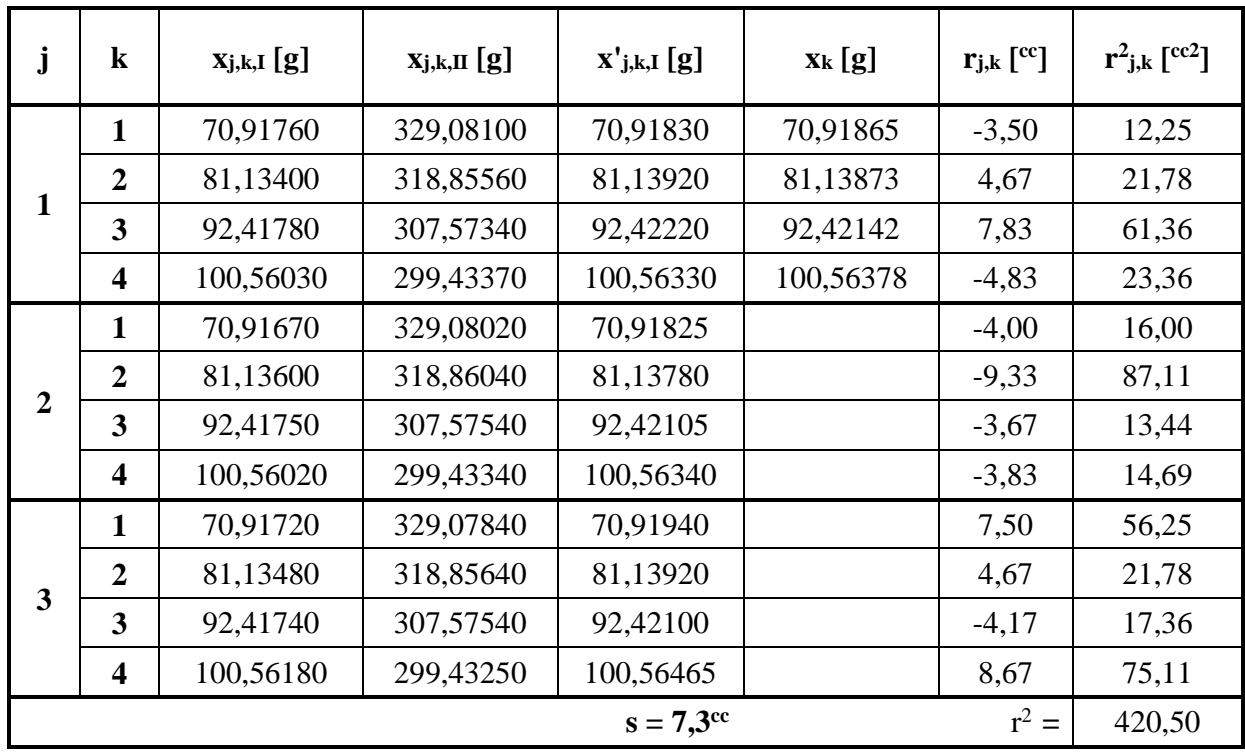

The resulting accuracy of South NTS-362R for horizontal angles is 0,68 mgon (Table 4). While resulting accuracy of South NTS-362R for vetical angles is 0,73 mgon (Table 5). So these are the values that are at the limit of accuracy the specified by the manufacturer and declared in a factory data (Table 1).

In this case, the values are exceeding the accuracy of the horizontal and vertical angle defined by the producer. These values are also greater than those obtained with the same instrument and the same method in better measurement conditions [2].

The results of measurement accuracy obtained by using a simplified method may raise doubts as to the value declared by the manufacturer, so the article attempts to verify the accuracy of measurement using statistical methods.

\section{VERIFICATION OF TOTAL STATIONS ANGLES MEASURING ACCURACY BY STATISTICAL METHODS}

To check the resulting measurement accuracy of total stations Trimble M3 and South NTS-362R and verify the correctness the performed procedure statistical tests: the sign test and the Shapiro-Wilk test were used. While to verify measuring accuracy declared by the manufacturers test $\chi^{2}$ was used $[2,3,4,5,6]$.

Systematic influence of factors on the average value in the series of measurements can be determined using the sign test. This test, as the name suggests, is based on 
signs of differences between pairs of successive observations (whether they are negative or positive). You can specify the probabilities associated with all the proportions (occurrence of $+/$ - signs) that could occur. Knowing the probability of each directional change, you can assess whether the results are significant $[4$, $5,6]$. In order to verify that the measurements are not affected by systematic errors signs test offered in the package Statistica 7.0 was used. The method of verification of the hypotheses proposed in this program was also used. If the level of significance for the designated value of the statistics is less than the assumed level of significance ( $p$-value $<0,05$ ) the hypothesis that the measurements do not contain systematic errors should be adopted (Table 6 and 7).

Table 6. Results of sign test for Trimble M3 1"

\begin{tabular}{|l|c|l|}
\hline Observations & The calculated value of statistics & $\mathrm{p}$-value \\
\hline Horizontal angles & 3,175426 & 0,001496 \\
\hline Vertical angles & 3,175426 & 0,001496 \\
\hline
\end{tabular}

Table 7. Results of sign test for SOUTH NTS-365R

\begin{tabular}{|l|c|l|}
\hline Observations & The calculated value of statistics & p-value \\
\hline Horizontal angles & 3,175426 & 0,001496 \\
\hline Vertical angles & 2,598076 & 0,009375 \\
\hline
\end{tabular}

There is a lack of systematic errors in both cases, which leads us to the conclusion about the suitability of the tested equipment for surveying.

Test Shapiro-Wilk test is a non-parametric test of the random variable as (1) [4, $5,6]$ :

$$
W=\frac{\left(\sum_{i} a_{i}(n)\left(x_{n=i+1}-x_{i}\right)\right)^{2}}{\sum_{j}\left(x_{j}-\bar{x}\right)^{2}}
$$

where:

$x_{j q} \quad$ - value of the elements of sample,

$a_{i}(n)$ - constants (tabulated in the tables Shapiro-Wilk)

If the determined statistics $\mathrm{W}$, belongs to the interval $\left(W_{d}(1 / 2 \alpha ; n) ; \infty\right)$ there are no grounds to reject the hypothesis of normal distribution of measurement errors, hence the request for the normal distribution of errors. The lower limit of the range for $\alpha=0,05$, read from the Shapiro-Wilk tables is $W_{d}=0,828$.

The calculated value of the Shapiro-Wilk statistic for horizontal angles W= 0,98331 belongs to the interval $(0,828 ; \infty)$, so normal distribution of errors and proper operation of Trimble total station for measuring horizontal angles can be concluded. 
The calculated value of the Shapiro-Wilk statistic for vertical angles $\mathrm{W}=0,87833$ belongs to the interval $(0,828 ; \infty)$, so normal distribution of errors and proper operation of Trimble total station for measuring vertical angles can be concluded.

The calculated value of the Shapiro-Wilk statistic for horizontal angles $\mathrm{W}=0,96040$ belongs to the interval $(0,828 ; \infty)$, so normal distribution of errors and proper operation of SOUTH total station for measuring horizontal angles can be concluded.

The calculated value of the Shapiro-Wilk statistic for vertical angles $\quad W=$ 0,92182 belongs to the interval $(0,828 ; \infty)$, so normal distribution of errors and proper operation of SOUTH total station for measuring vertical angles can be concluded.

The $\chi 2$ test was used to check whether the accuracy of the angle measurement is less than or equal to the value declared by the manufacturer at the significance level of 0.05. $\chi 2$ test is the most commonly used test. You can use it to examine the compatibility of both characteristics: measurable and immeasurable [5, 6]. If the results of the measurements are normally distributed and the number of results is less than $50 \chi^{2}$ test can be used (2):

$$
\chi^{2}=\frac{\sqrt{v} \cdot s}{\sigma},
$$

gdzie:

$$
\begin{array}{ll}
\chi^{2} & \text { - value of } \chi^{2} \text { statistics, } \\
\mathrm{s} & \text { - an estimate of the standard deviation, } \\
\sigma & \text { - standard deviation, } \\
v & \text { - degrees of freedom, } v=(3-1) \cdot(4-1)=8 .
\end{array}
$$

The value of $\chi^{2}{ }_{1-\alpha}(v)$ statistics is read from the $\chi^{2}$ test tables. The rejection area is $P\left(\chi^{2}<\chi_{\alpha}^{2}\right)=\alpha$. If the determined $\chi^{2}$ statistics, belongs to the $\left(0, \chi_{\alpha}^{2}\right]$ interval There is a reason to reject the hypothesis that the estimate of the standard deviation obtained in simplified method of total station testing is equal to measurement accuracy declared by the manufacturer.

Table 8. The results of $\chi^{2}$ test for Trimble M3 1"

\begin{tabular}{|l|c|c|c|}
\hline Observations & $\begin{array}{c}\text { The calculated value } \\
\text { of } \chi^{2} \text { statistics }\end{array}$ & $\left(0 ; \chi^{2}{ }_{\alpha}\right)$ & $\begin{array}{c}\text { Compliance with the declared } \\
\text { measurement accuracy }\end{array}$ \\
\hline $\begin{array}{l}\text { Horizontal } \\
\text { angles }\end{array}$ & 2,828 & $(0 ; 2,732)$ & + \\
\hline $\begin{array}{l}\text { Vertical } \\
\text { angles }\end{array}$ & 2,828 & $(0 ; 2,732)$ & + \\
\hline
\end{tabular}


Table 9. The results of $\chi^{2}$ test for South NTS-362R

\begin{tabular}{|l|c|c|c|}
\hline Observations & $\begin{array}{c}\text { The calculated value } \\
\text { of } \chi^{2} \text { statistics }\end{array}$ & $\left(0 ; \chi^{2}{ }_{\alpha}\right)$ & $\begin{array}{c}\text { Compliance with the declared } \\
\text { measurement accuracy }\end{array}$ \\
\hline $\begin{array}{l}\text { Horizontal } \\
\text { angles }\end{array}$ & 3,206 & $(0 ; 2,732)$ & + \\
\hline $\begin{array}{l}\text { Vertical } \\
\text { angles }\end{array}$ & 3,441 & $(0 ; 2,732)$ & + \\
\hline
\end{tabular}

On the basis of the analyzes (Table 8 and 9) it may be stated that tested equipment meets declared accuracy of measuring horizontal and vertical angles.

\section{CONCLUSIONS}

Based on conducted measurements and tests following conclusions can be formulated:

- signs test showed no influence of systematic errors of horizontal and vertical angles measurements with both instruments,

- Shapiro-Wilk statistic confirmed normal distributions of errors and correctness of total stations angle measurements,

- the $\chi^{2}$ test showed that tested equipment meets declared accuracy of measuring horizontal and vertical angles,

- equipment is suitable for making geodetic measurements.

\section{REFERENCES}

1. PN-ISO 17123-3 wrzesień 2005, Optyka i instrumenty optyczne, Terenowe procedury testowania instrumentów geodezyjnych i pomiarowych, Część 3 , Teodolity.

2. Skrzypczak I., Oleniacz G., Zientek D.: Analiza dokładności teodolitów elektronicznych za pomoca testów statystycznych $w$ oparciu o uproszczona procedure testowania terenowego, Zeszyty Naukowe Politechniki Rzeszowskiej, Budownictwo i Inżynieria Środowiska, Zeszyt 59, nr 1/2010/II, Oficyna Wydawnicza Politechniki Rzeszowskiej, Rzeszów, 2012.

3. Godek K., Krupiński W.: Metodyka oceny sprzętu geodezyjnego za pomoca testów statystyki matematycznej, Infrastruktura i ekologia terenów wiejskich, $\mathrm{Nr}$ 6/2010, PAN, Oddział Kraków, s. 167-175, Komisja Technicznej Infrastruktury wsi.

4. Krupiński W.: Sposoby badania zgodności rozkładów błędów niektórych pomiarów geodezyjnych z rozkładami teoretycznymi, ZN AR, Kraków, seria Geodezja 3, 83, 1973. 
5. Gajek L., Kałuszka M.: Wnioskowanie statystyczne. Modele i metody, WN-T, Warszawa, 1996.

6. Hellwig Z.: Elementy rachunku prawdopodobieństwa $i$ statystyki matematycznej, Wydawnictwo Naukowe PWN, Warszawa, 1995.

\section{ANALIZA DOKŁADNOŚCI POMIARÓW KĄTOWYCH TACHIMETRAMI ELEKTRONICZNYMI TRIMBLE M3 1" ORAZ SOUTH NTS-362R}

\section{Streszczenie}

Głównym celem niniejszych badań było uzyskanie informacji o rzeczywistej dokładności pomiarów kątowych dwoma instrumentami (Trimble M3 1" oraz South NTS-362R), możliwej do uzyskania $\mathrm{w}$ danych warunkach pomiarowych. Cel ten zrealizowano wykorzystując uproszczoną metodę testowania instrumentów zawartą w normie PN-ISO 17123-3 [1]. Jest to kontynuacja badań opisanych w [2], przeprowadzonych na tej samej bazie testowej jednak tym razem $\mathrm{w}$ odmiennych, mniej sprzyjających warunkach polowych. Wykorzystanie w testach tego samego instrumentu stworzyło możliwość porównania i analizy uzyskanych parametrów. Zakres prac obejmował wykonanie pomiarów oraz zestawienie i opracowanie ich wyników dla obu instrumentów wraz z obróbką statystyczną otrzymanych rezultatów.

Słowa kluczowe: norma ISO, pomiar kątów, analiza dokładności

Editor received the manuscript: 20.10 .2016 